Ann. Biol. anim. Bioch. Biophys., I976, 16 (3), 3I5-3I8.

\title{
CHANGES IN THE ACTIVITY OF AN ALKALINE PHOSPHATASE IN PREPUBERAL MOUSE OVARIES
}

\author{
T. A. BRAMLEY, Jane SAGE, Joyce KENT and Margaret RYLE
}

Department of Clinical Endocrinology,

The Birmingham and Midland Hospital for Women, Showell Green Lane, Sparkhill, Birmingham, B11 $4 H L$

SUMMARY

An alkaline phosphatase which occurs in immature mouse ovaries has been studied. Its activity was enhanced by gonadotrophins with luteinizing hormone ( $\mathrm{LH})$ activity. In control mice its level fluctuated markedly with age, following the pattern of serum LF concentration. The capacity of the ovary to produce more of this enzyme in response to injected hormone also varied with age. During a refractory period injected gonadotrophin induced the synthesis of much oestrogen, whereas during a responsive period much less oestrogen was produced. The possible role of this enzyme is discussed.

\section{INTRODUCTION}

An alkaline phosphatase may be demonstrated in immature mouse ovaries by standard histochemical methods (BEN-OR, I963; BRANDAU, I970 ; KENT and RYLE, 1975). Another alkaline phosphatase, which we have termed alkaline phosphatase I (Alk.Ph.I) is also demonstrable in such ovaries (BRAMLEY, I974), but its substrate requirements, $\mathrm{pH}$ optimum and susceptibility to various inhibitors are quite distinct (table I). Both enzymes occur in the follicular theca, stroma and interstitial tissue of the ovary (KENT and RYLE, I975; BRAMLEY and KENT, in preparation) and, at certain stages of development, the activity of each is augmented by injected gonadotrophins (BRAMLEY, in press; BRAMLEY and KENT, in preparation).

In homogenates of ovaries from $2 \mathrm{I}$ day old mice, of the CFW strain, the specific activity of Alk.Ph.I is low. However, treatment of the mice with human chorionic gonadotrophin $(\mathrm{hCG})$ or human luteinizing hormone $(\mathrm{hLH})$ results in a sharp increase in specific activity and also a marked rise in the affinity with which it binds to the 
substrate $\left(\mathrm{K}_{m}\right)$. These changes do not become apparent until 6-8 $\mathrm{h}$ after injection and only reach maximal levels after $24 \mathrm{~h}$ (BRAMLEY, I974). This distinct activity has been designated alkaline phosphatase $\mathrm{Ib}$ (Alk.Ph.Ib). Its substrate requirements, $\mathrm{pH}$ optimum, inhibitor sensitivity, etc. are similar to those for Alk.Ph.I. It is induced specifically by gonadotrophins with $\mathrm{LH}$ activity. Nevertheless, although human follicle stimulating hormone alone is ineffective, it augments the effects of $h \mathrm{LH}$ and hCG when administered simultaneously (BRAMLEY, 1974).

TABI,E I

Alkaline phosphatase activities in mouse ovaries which respond to gonadotrophins

\begin{tabular}{|c|c|c|}
\hline & $\begin{array}{l}\text { Demonstrated } \\
\text { by Gomori's calcium } \\
\text { cobalt method }\end{array}$ & Alkaline phosphatase I \\
\hline Optimal pH & 9.' & 10.1 \\
\hline Substrates & $\begin{array}{l}\text { Wide range of organic } \\
\text { substrates hydrolyzed }\end{array}$ & $\begin{array}{l}p \text {-nitrophenyl phosphate } \\
\text { and naphthylphosphate } \\
\text { hydrolyzed most rapidly }\end{array}$ \\
\hline $\mathrm{Ca}^{2+}$ & $87 \mathrm{mM} \mathrm{CaCl} 2$ in medium & $\mathrm{Ca}^{2+}$ inhibits \\
\hline Iodoacetate & Inactivates & No effect \\
\hline N-ethylmaleimide & Inactivates & No effect \\
\hline EDTA + Glycine & No effect & Inactivates \\
\hline
\end{tabular}

Although Alk.Ph.I and Alk.Ph.Ib are remarkably similar enzymically, their chemical and physical properties are quite distinct. Studies of these properties suggest that the weakly active Alk.Ph.I is composed of the highly active Alk.Ph.Ib associated with an inhibitory protein, which is rich in sialic acid. Gonadotrophin treatment in vivo appears to dissociate this complex and to allow full expression of the Alk.Ph.Ib activity (BRAMLEY, unpublished data).

\section{AGE-RELATED VARIATIONS \\ IN ALKAIINE PHOSPHATASE ACTIVITY}

During normal development the ovarian content of Alk. $\mathrm{Ph}$.Ib fluctuates markedly (BRANLEY, in press). The changes in substrate binding affinity $\left(\mathrm{K}_{m}\right)$ follow the pattern of changes in the serum content of LH (DULLAART, KENT and RYLE, 1975). There is an initial increase until about 6 days after birth. A high level is maintained until I2 days, then the substrate binding affinity declines rapidly. Thereafter it remains low until shortly before puberty. There is, in addition, on Day 20 after birth, a rise in specific activity with no associated marked increase in binding affinity, 
suggesting an enhanced level of Alk.Ph.I but not of Alk.Ph.Ib. This level of specific activity is maintained until Day 35 after which Alk.Ph.Ib increases progressively until ovulation occurs at Day 40 to 45 .

The capacity to respond to exogenous gonadotrophin also varies dramatically with age (BRAMLEY, in press). There is no response to injections of hCG (5 iu/ro g body weight) until I 8 days after birth. Before Day 9 high endogenous LH levels may already be inducing a maximal response. From Day io to I6, however, serum LH levels are declining or low and some other factor must be limiting the capacity to respond to exogenous hormone. From Day 18 to 29 both specific activity and substrate binding affinity are progressively and markedly enhanced by $\mathrm{hCG}$, indicating increasing activation of $\mathrm{Alk}$. $\mathrm{Ph}$.Ib. A further somewhat refractory period follows from Day 30 to 35 but subsequently the capacity to respond again increases progressively until the time of the first ovulation.

\section{DISCUSSION}

Assuming that Alk.Ph.Ib is derived from Alk.Ph.I, the fluctuations in the capacity to respond to injected hCG may reflect variations in the ovarian content of the latter. What controls the supply of Alk.Ph.I ? DöHLER and WUTTKE (I974), using rats, found age-related changes in serum prolactin levels which closely parallel the mouse ovarian alkaline phosphatase response to hCG. This suggests that prolactin may control the ovarian supply of Alk. Ph.I available for the production of Alk.Ph.Ib.

Finally what is the function of Alk.Ph.Ib ? Between Days 30 and 33, the second refractory period, hCG injections induce rapid oestrogen secretion and a massive increase in uterine weight. In contrast between Days 22 and 29, when hCG markedly enhances the activity of Alk.Ph.Ib, its effects on oestrogen secretion and uterine weight are much less (BRAMLEY, in press). Thus much oestrogen is produced in response to hCG when the enhancement of Alk.Ph.Ib activity is weak and vice versa. It is possible that the function of Alk.Ph.Ib, induced by gonadotrophins, is to switch off the oestrogen synthesizing mechanism.

$\mathrm{LH}$ and $\mathrm{hCG}$ rapidly activate mouse ovarian adenyl cyclase to produce cyclic AMP (KUEHL et al., 1970). This in turn may stimulate protein kinases (KUO et al., r970) to phosphorylate certain proteins essential for steroidogenesis. The same hormones activate, but more slowly, Alk.Ph.I. to Alk.Ph.Ib which may dephosphorylate the same proteins, so serving as a regulator to prevent excessive oestrogenic stimulation at certain stages of development. The overall effects of LH during normal prepubertal growth may thus fluctuate, depending not only on the serum concentration of this hormone but also on the varying supply of Alk.Ph.I and on its control. 


\section{RÉSUMÉ}

\section{MODIFICATIONS DE L'ACTIVITÉ DE LA PHOSPHATASE ALCALINE DANS LES OVAIRES DE SOURIS PRÉPUBÈRE}

Une phosphatase alcaline apparait dans l'ovaire de Souris immature. Son activité est augmentée par les gonadotropines à activité $\mathbf{L H}$. Son niveau varie fortement avec l'âge en fonction de l'évolution de la LH plasmatique. La capacité de l'ovaire à produire davantage de cette enzyme en réponse à une gonadotropine exogène varie également avec l'âge : on n'observe aucune réponse jusqu'à 18 jours après la naissance et entre 30 et 35 jours la réponse est plus faible qu'à 28-29 jours ou après 35 jours.

L'injection de gonadotropine pendant une période réfractaire augmente la synthèse d'estrogène, si l'injection est faite pendant une période sensible, la synthèse d'estrogène est moins importante. Le rôle de cette phosphatase induite par les gonadotropines pourrait être de changer le mécanisme de synthèse des estrogènes.

\section{REFERENCES}

BEN-OR S., 1963. Morphological and functional development of the mouse ovary. I. Morphology and histochemistry of the developing ovary in normal conditions and after FSH treatment. $J$. Embryol. exp. Morph., 11, I-10.

Bramley T., I974. Treatment of immature mice with gonadotrophins. Effects on some enzymic activities of unfractionated ovarian homogenates. Biochem. J., 140, 45I-460.

Bramley T. Treatment of immature mice with gonadotrophins. The influence of mouse age on the response of ovarian alkaline phosphatase activities to gonadotrophins. Biochem. $J$. (in press).

Brandau H., 1970. Histochemical localization of enzyme activities in infant and gonadotrophin stimulated mouse ovaries. In Gonadotrophins and Ovarian Development, p. 307-3II. Eds. W. R. BUTT, A. C. CROoKe and M. RYLE. Livingstone, Edinburgh.

Döhler K., Wuttke W., I974. Serum LH, FSH, prolactin and progesterone from birth to puberty in female and male rats. Endocrinology, 94, 1003-1008.

DullaArt J., Kent J., Ryle M., 1975. Serum gonadotrophin concentrations in infantile female mice. J. Reprod. Fert., 43, 189-192.

KENT J., RYLE M., 1975. Histochemical studies on three gonadotrophin-responsive enzymes in the infantile mouse ovary. J. Reprod. Fert., 42, 519-536.

Kuehl F. A., Hurnes J. L., Tarnoff J., Cirillo V. J., Ham E. A., I97o. Prostaglandin receptor site : evidence for an essential role in the action of luteinizing hormone. Science, 169, 883-886.

Kuo J. F., Kreuger B. K., Sanes J. R., Greingard P., I97o. Cyclicnucleotide dependent protein kinases. V. Preparation and properties of adenosine $3^{\prime}, 5^{\prime}$-monophosphate-dependent protein kinase from various bovine tissues. Biochim. Biophys. Acta., 212, 79-9I. 